\title{
KONTRIBUSI PEMBELAJARAN DI PERGURUAN TINGGI DAN LITERASI KEUANGAN TERHADAP PERILAKU KEUANGAN MAHASISWA
}

\author{
Nyoman Trisna Herawati \\ Universitas Pendidikan Ganesha, Jl.Udayana 11 Singaraja \\ e-mail : aris_herawati@yahoo.co.id
}

\begin{abstract}
The Contribution of Learning in University and Financial Literacy To Student's Financial Behaviour. The objective of this research is to determine the contribution of: (1) learning in university to student's financial behavior, (2) the financial literacy to student's financial behavior, (3) learning in university and financial literacy simultaneously to student's financial behavior. The design of this research is explanatory research, which examines the contribution between learning in university and financial literacy to student's financial behavior. The population in this study is all students of the Faculty of Economics and Business Undiksha. Data were collected using a questionnaire and analyzed using descriptive statistics and path analysis (path analysis) using SPSS version 16.0 for windows. The result shows that learning in university does not contribute significantly to the financial behavior of the students. Financial literacy contributes positively and significantly to the financial behavior of students. Simultaneously learning in university and financial literacy are signifycantly contributing to the financial behavior of students. In general, the level of financial literacy of students at Faculty of Economics and Business comes within the low category.
\end{abstract}

Keywords: financial behavior, financial literacy, learning in university

\begin{abstract}
Abstrak: Kontribusi Pembelajaran di Perguruan Tinggi dan Literasi Keuangan terhadap Perilaku Keuangan Mahasiswa. Tujuan penelitian ini untuk mengetahui kontribusi: (1) pembelajaran di perguruan tinggi terhadap perilaku keuangan mahasiswa, (2) literasi keuangan terhadap perilaku keuangan mahasiswa, (3) pembelajaran di perguruan tinggi dan literasi keuangan secara simultan terhadap perilaku keuangan mahasiswa. Rancangan penelitian ini adalah penelitian eksplanatori (explanatory research) yang mengkaji kontribusi antara pembelajaran di perguruan tinggi dan literasi keuangan terhadap perilaku keuangan mahasiswa. Populasi dalam penelitian ini adalah seluruh mahasiswa Fakultas Ekonomi dan Bisnis Undiksha. Data dikumpulkan dengan menggunakan kuesioner. Teknik analisis data menggunakan statistik deskriptif dan analisis jalur (path analysis) dengan bantuan SPSS versi 16.0 for windows. Hasil penelitian menunjukkan bahwa pembelajaran di perguruan tinggi tidak berkontribusi secara signifikan terhadap perilaku keuangan mahasiswa. Literasi keuangan berkontribusi positif dan signifikan terhadap perilaku keuangan mahasiswa. Secara simultan pembelajaran di perguruan tinggi dan literasi keuangan berkontribusi secara signifkan terhadap perilaku keuangan mahasiswa. Secara umum tingkat literasi keuangan mahasiswa Fakultas Ekonomi dan Bisnis tergolong masih rendah.
\end{abstract}

Kata-kata Kunci: literasi keuangan, pembelajaran di perguruan tinggi, perilaku keuangan

Literasi keuangan dewasa ini merupakan topik yang menjadi perhatian setiap negara termasuk Indonesia. Perkembangan ekonomi global dewasa ini, membawa perubahan ke dalam sistem keuangan masyarakatnya. Hal ini dapat dilihat dari kompleksitas jasa produk keuangan yang ditawarkan kepada masyarakat, ditambah dampak teknologi terhadap produk dan jasa keuangan serta peningkatan akses terhadap kredit. Jika hal ini tidak diimbangi dengan pengetahuan keuangan yang memadai, maka dapat menjerumuskan masyarakatnya ke dalam berbagai masalah keuangan. 
Di Indonesia melalui lembaga Otoritas Jasa Keuangan (OJK) telah berupaya untuk meningkatkan pemahaman masyarakat dan konsumen mengenai Lembaga Jasa Keuangan (LJK) serta produk dan jasa yang ditawarkan pada Industri keuangan. Dengan demikian tingkat pengetahuan mengenai industri keuangan akan meningkat dan pada akhirnya akan meningkatkan tingkat utilitas dan kepercayaan masyarakat serta konsumen terhadap lembaga dan produk jasa keuangan di Indonesia (financial well-literate). Pengetahuan keuangan merupakan dimensi yang tidak terpisahkan dari literasi keuangan, namun belum dapat menggambarkan literasi keuangan seseorang. Literasi keuangan memiliki dimensi aplikasi tambahan yang menyiratkan bahwa seseorang harus memiliki kemampuan dan kepercayaan diri untuk menggunakan pengetahuan finansialnya untuk membuat keputusan. Literasi keuangan terjadi manakala seorang individu memiliki sekumpulan keahlian dan kemampuan yang membuat orang tersebut mampu memanfaatkan sumber daya yang ada untuk mencapai tujuan. Individu yang memiliki kemampuan untuk membuat keputusan yang benar tentang keuangan tidak akan memiliki masalah keuangan di masa depan dan dapat menunjukkan perilaku keuangan yang sehat serta mampu menentukan prioritas kebutuhan bukan keinginan (Chinen dan Endo, 2012).

OJK menyebutkan bahwa indeks literasi keuangan di Indonesia hanya 21,7 persen, dibandingkan dengan penetrasi di Filipina yang sudah mencapai di atas 30\% dan Malaysia 60-70\%. Masyarakat di Indonesia dinilai belum begitu memahami produk keuangan seperti bank, asuransi, dan pasar modal. Tingkat literasi yang rendah ini disebabkan oleh kurang imbangnya tingkat pertumbuhan industri jasa keuangan dan kesadaran masyarakat terhadap produk keuangan. Di tengah industri keuangan yang berkembang pesat, masih saja ada masyarakat yang memilih menyimpan uang di rumah (Bisnis. Liputan.6.com, 2014). Di samping itu hasil survei menunjukkan bahwa tingkat akses keuangan masyarakat Indonesia relatif rendah. Hal ini dapat diamati dari jumlah tabungan dan utang rumah tangga Indonesia di bank. Hasil dari Survei Neraca Rumah Tangga (SNRT) Bank Indonesia 2011 menunjukkan bahwa jumlah rumah tangga di Indonesia yang memiliki rekening tabungan di bank di tahun 2011 hanya berkisar antara $43,57 \%$, sementara jumlah rumah tangga yang memiliki utang di bank hanya mencapai $19,58 \%$.
Diketahui dari hasil SNRT tersebut, sebagian besar rumah tangga Indonesia meminjam dari lembaga keuangan non-bank (seperti koperasi dan lembaga keuangan mikro) dan lembaga non-keuangan (seperti arisan, keluarga, teman, tetangga, lintah darat, dan non lembaga keuangan lain). (www.ojk.go.id/peran-bi, 2014)

Literasi keuangan berpengaruh signifikan terhadap perilaku keuangan (Danes dan Haberman, 2007; Laily, 2013; Susanti, 2013). Hasil penelitian Chen dan Volpe (1998) menunjukkan mahasiswa dengan tingkat literasi keuangan rendah lebih banyak memilih keputusan keuangan yang salah dibandingkan dengan mahasiswa yang memiliki tingkat literasi keuangan yang lebih tinggi. Temuan penelitian yang lain Robb dan Woodyard (2011) menunjukkan bahwa pengetahuan keuangan yang baik secara subjektif maupun objektif berpengaruh terhadap perilaku keuangan secara signifikan. Gutter (2008) mempertegas bahwa pengetahuan keuangan merupakan prediktor utama dalam membentuk perilaku keuangan. Perilaku keuangan yang sehat ditunjukkan oleh aktivitas perencanaan, pengelolaan serta pengendalian keuangan yang baik. Bijak tidaknya pengelolaan keuangan pribadi ini erat kaitannya dengan kemampuan serta pengetahuan seseorang akan konsep-konsep dalam literasi keuangan. Jadi, literasi keuangan mempengaruhi hampir semua aspek yang berhubungan dengan perencanaan dan pengeluaran uang termasuk perilaku keuangan seseorang.

Pembelajaran di perguruan tinggi berperan sangat penting dalam proses pembentukan literasi keuangan mahasiswa. Pembelajaran yang efektif dan efisien dapat mengembangkan seluruh ranah tujuan pembelajaran yaitu pengetahuan (kognitif), sikap (afektif) dan keterampilan (psikomotorik). Melalui berbagai metode pengajaran, media, dan sumber belajar yang sesuai dengan kompetensi, diharapkan mampu memberikan bekal kepada mahasiswa untuk memiliki kecakapan di bidang keuangan, sehingga mahasiswa menjadi siap dan mampu menghadapi kehidupan saat ini maupun masa depan yang semakin kompleks (Lutfi dan Iramani, 2008). Selain itu pendidikan keuangan memiliki peran yang sangat penting bagi mahasiswa untuk memiliki kemampuan memahami, menilai, dan bertindak dalam kepentingan keuangan mereka.

Tidak dipungkiri bahwa pengetahuan keuangan sebagai hasil pembelajaran keuangan, secara teoritis keberhasilannya sangat terkait dengan proses belajar mengajar. Proses pembelajaran 
dan teknik asesmen yang digunakan dosen turut menentukan keberhasilan mahasiswa dalam memahami dan mengimplementasikan materi yang diterima dalam kehidupan sehari-hari (Trianto, 2009). Belajar akan lebih baik dengan pelajaran yang relevan dengan menggunakan metode pembelajaran aktif. Keahlian yang penting harus dipraktekkan oleh mahasiswa agar benar-benar tertanam dalam diri mereka dan bermanfaat untuk hidup mereka.

Beberapa penelitian menunjukkan bahwa terdapat pengaruh pembelajaran keuangan di perguruan tinggi terhadap literasi keuangan. Jhonson dan Margaret (2007) menyatakan bahwa pendidikan keuangan mempunyai peran yang sangat penting bagi mahasiswa sehingga memiliki kemampuan memahami, menilai, dan bertindak dalam kepentingan keuangan mereka. Gutter (2008) dalam penelitiannya menyatakan bahwa pendidikan keuangan berpengaruh positif signifikan terhadap pengetahuan keuangan. Hal ini diperkuat oleh penelitian Lutfi dan Iramani (2008), Susanti (2010), Widayanti (2011), yang menyatakan bahwa pendidikan keuangan di perguruan tinggi berpengaruh terhadap literasi keuangan.

Literasi keuangan tidak diperoleh secara eksplisit dalam pembelajaran di sekolah maupun di perguruan tinggi. Jika ada mata kuliah manajemen keuangan, lebih menekankan pada seluk beluk keuangan dalam perusahaan, sehingga pelajaran menggunakan uang tidak ada sama sekali. Jadi kita bisa melihat bahwa perguruan tinggi atau sekolah hanya berusaha memenuhi kebutuhan suatu industri, bukan kebutuhan akan penggunaan uang oleh manusianya sendiri. Padahal dalam kehidupan ilmu pengelolaan uang (literasi keuangan) sangatlah penting agar dapat memenuhi kebutuhan hidup dengan lebih baik. Beberapa kasus menyebutkan terdapat beberapa lulusan perguruan tinggi yang mengalami kegagalan di dunia kerja, bukan karena kemampuannya yang tidak diakui melainkan kejujuran dalam urusan keuangan yang bermasalah. Ternyata, lulusan yang sudah bekerja mapan, dengan penghasilan tertentu tetap memiliki masalah dalam keuangan. Kasus yang lain, masih banyak lulusan yang tergiur dengan investasi yang menjanjikan namun tidak dapat dipertanggungjawabkan. Hal ini menyebabkan mereka harus terlilit utang yang berkepanjangan yang tentu saja sangat merugikan dirinya dan orang lain. Di Bali sendiri banyak kasus penipuan yang berbalut investasi bodong seperti Koperasi Karangasem Membangun (KKM) tahun 2009, PT Balicon, dan bisnis iuran lainnya yang menawarkan investasi dengan imbalan yang sangat fantanstis. Hal ini bisa terjadi karena masyarakat kita belum memiliki literasi keuangan yang baik.

Literasi keuangan juga merupakan landasan menjadi seorang wirausaha yang sukses. Pengetahuan kewirausahaan (entrepreneurship) yang telah diberikan melalui mata kuliah kewirausahaan lebih menekankan pada aspek teknis, dan kurang memberikan filosofi dalam pengelolaan keuangannya. Hal ini dapat dilihat dari kegagalan beberapa usaha yang baru dirintis mengalami kebangkrutan karena pengelolaan keuangannya yang kurang baik. Para remaja/mahasiswa, kelak suatu saat akan bekerja. Baik bekerja pada orang lain (sebagai karyawan) maupun membuka pekerjaan untuk diri sendiri (berwirausaha). Hasil dari bekerja adalah penghasilan yang akan digunakan untuk memenuhi kebutuhan hidup dan mengembangkan usaha. Sangatlah penting pemahaman akan pengetahuan pengelolaan keuangan yang baik mulai dikenalkan sejak dini, sebelum memiliki penghasilan termasuk juga pemahaman akan investasi. Nantinya, setelah memiliki pengahasilan, mahasiswa dapat mampu mengelola dengan bijak dan akhirnya dapat memperoleh kebahagian hidup yang diharapkan.

Berdasarkan paparan di atas, maka tujuan penelitian ini untuk mengetahui kontribusi: (1) pembelajaran di perguruan tinggi terhadap perilaku keuangan mahasiswa, (2) literasi keuangan terhadap perilaku keuangan mahasiswa, (3) pembelajaran di perguruan tinggi dan literasi keuangan secara simultan terhadap perilaku keuangan mahasiswa.

\section{METODE}

Rancangan penelitian ini adalah penelitian eksplanatori (explanatory research) yang mengkaji kontribusi antara pembelajaran di perguruan tinggi dan literasi keuangan terhadap perilaku keuangan mahasiswa. Populasi dalam penelitian ini merupakan seluruh mahasiswa Fakultas Ekonomi dan Bisnis Undiksha. Teknik pengambilan sampel dilakukan melalui purposive sampling dengan jumlah anggota sampel sebanyak 100 mahasiswa yang terdiri atas mahasiswa Jurusan Akuntansi S1, Jurusan Manajemen S1, Jurusan Pendidikan Ekonomi, dan Jurusan Akuntansi D3. Data dikumpulkan dengan menggunakan kuesioner yang diberikan secara langsung kepada responden. Teknik analisis data menggunakan statistik deskriptif dan analisis jalur (path analysis) 
dengan bantuan SPSS versi 16.0 for window. Analisis jalur (path analysis) digunakan untuk menganalisis pola hubungan antar variabel dengan tujuan untuk mengetahui pengaruh langsung maupun tidak langsung seperangkat variabel bebas/eksogen terhadap variabel terikat/endogen (Sarwono, 2011; Riduwan \& Kuncoro, 2013).

Dalam penelitian ini, terdapat 3 (tiga) variabel yaitu dua variabel bebas yaitu pembelajaran di perguruan tinggi $\left(\mathrm{X}_{1}\right)$ dan literasi keuangan $\left(\mathrm{X}_{2}\right)$ dan satu variabel terikat yakni perilaku keuangan $(\mathrm{Y})$. Pembelajaran di perguruan tinggi $\left(\mathrm{X}_{1}\right)$ didefinisikan sebagai pembelajaran dalam materi keuangan yang terkait dengan pemahaman literasi keuangan mahasiswa. Indikatornya meliputi, (1) pemahaman materi dalam matakuliah keuangan yang relavan, (2) metode dan media yang digunakan, (3) proses dan asesmen pembelajaran. Skala pengukuran yang dipakai adalah skala likert $1 \mathrm{~s} / \mathrm{d} 5$ yaitu (1) tidak pernah, (2) jarang, (3) kadang-kadang, (4) sering, (5) selalu. Kuesioner berisikan 10 item pernyataan yang diadaptasi dari penelitian Widayanti, (2011) dengan beberapa revisi untuk menyesuaiakan dengan tujuan penelitian ini. Literasi keuangan merupakan kemampuan dan keahlian yang dimiliki seseorang untuk mengelola sumber daya yang dimiliki untuk meraih tujuan keuangan di masa kini dan masa yang akan datang. Kemampuan dan keahlian tersebut diperoleh dari pengetahuan keuangan yang meliputi: (1) pengetahuan umum mengenai konsepkonsep dasar keuangan, termasuk di antaranya pengetahuan mengenai bunga majemuk dan per- bedaan nilai nominal dan nilai riil (2) pengetahuan dasar mengenai keuangan pribadi (basic personal finance), (3) manajemen uang (money manajement), (4) manajemen kredit dan utang (credit and debt manajemen), (5) tabungan dan investtasi (saving and investement) serta (6) manajemen resiko (risk manajement). Variabel ini diukur dengan menggunakan tes dengan 8 buah pertanyaan yang diadaptasi dari kuis literasi keuangan yang diakses di www.usfinancialcapability.org/quiz.php dengan beberapa revisi. Perilaku keuangan mahasiswa adalah perilaku dalam mengelola keuangan pribadinya dalam hal ini mengatur penggunaan uang saku yang diberikan orang tua dengan lebih bijak. Perilaku keuangan ini dapat ditunjukkan melalui hal-hal antara lain: (1) penggunaan prinsip ekonomi untuk memenuhi kebutuhan dan (2) melakukan perencanaan keuangan untuk masa kini dan masa depan. Skala pengukuran yang dipakai adalah skala likert $1 \mathrm{~s} / \mathrm{d}$ 5 yaitu (1) tidak pernah, (2) jarang, (3) kadangkadang, (4) sering, (5) selalu. Kuesioner berisikan 10 item pernyataan yang diadaptasi dari penelitian Widayanti (2011) dan Susanti (2013) dengan beberapa revisi disesuaikan dengan tujuan penelitian ini.

Kerangka hubungan kausal empiris antara jalur (X1 terhadap Y, X2 terhadap Y, dan X1, X2 terhadap $\mathrm{Y}$ ) dapat dibuat melalui persamaan struktural sebagai berikut.

$$
Y=\rho_{y x 1} x 1+\rho_{y x 2} x 2+\rho_{y} \varepsilon
$$

Model persamaan jalurnya dapat dilihat dalam Gambar 1.

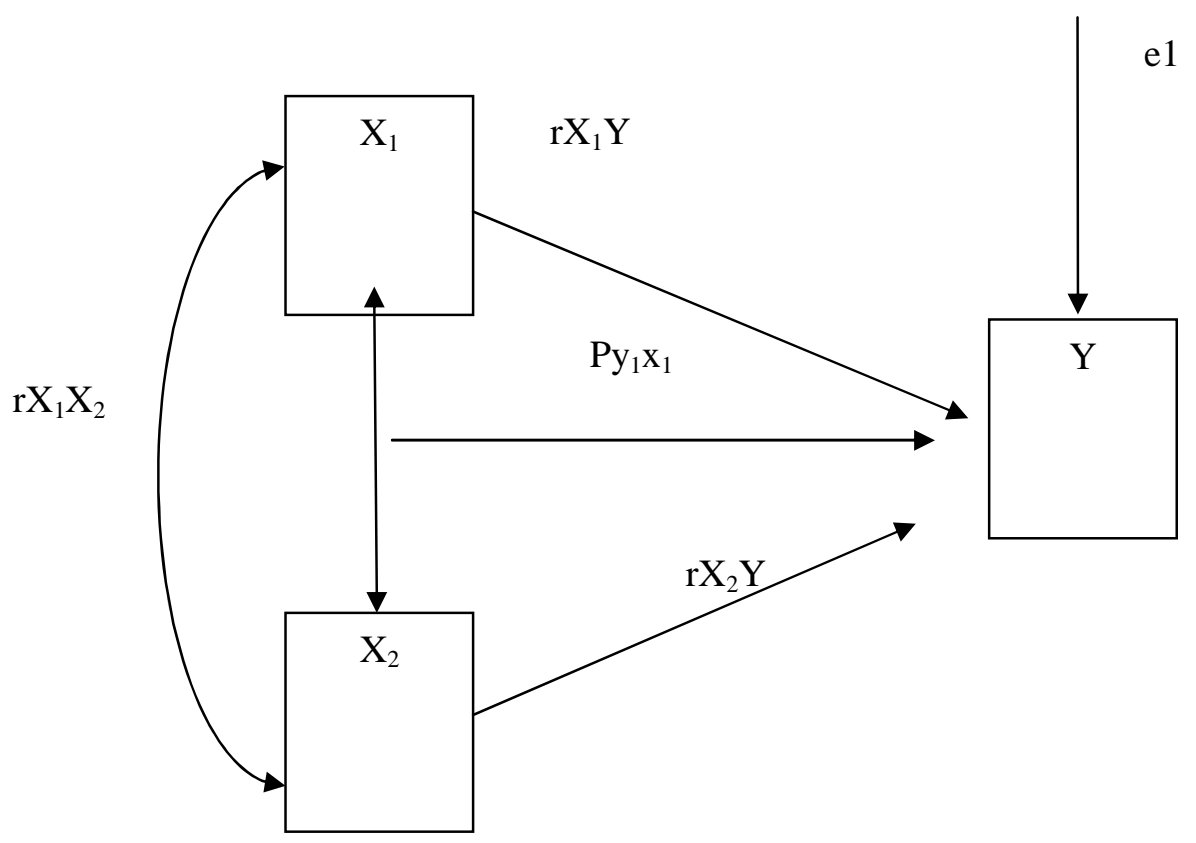

Gambar 1. Model Persamaan Jalur 


\section{HASIL DAN PEMBAHASAN}

\section{Hasil}

Tingkat literasi keuangan pada mahasiswa Fakultas Ekonomi dan Bisnis dapat dilihat dalam Tabel 2. Perhitungan tingkat literasi keuangan adalah membagi jumlah jawaban yang benar dengan jumlah seluruh jawaban. Nilai terendah adalah 12,5\% (hanya menjawab 1 benar dari 8 pertanyaan yang ada) dan tertinggi adalah $100 \%$ (semuanya benar). Pengklasifikasian menurut Chen dan Volpe (1998) membagi tingkat literasi seseorang dengan rentangan sebagai berikut. (1) Kelompok rendah dengan skor $<60 \%$, (2) kelompok sedang dengan skor $60 \%$ s/d $79 \%$, dan (3) kelompok tinggi dengan skor $\geq 80 \%$. Jadi dapat dilihat bahwa secara keseluruhan tingkat rata- rata (mean) literasi keuangan mahasiswa Fakultas Ekonomi dan Bisnis tergolong masih rendah. Dari keempat jurusan yang dijadikan subjek penelitian, Jurusan Akuntansi S1 memiliki tingkat rata-rata (mean) literasi keuangan tertinggi yang tergolong sedang. Namun dilihat dari rata-rata $65 \%$ maka dapat dikatakan sedang cenderung rendah. Nilai standar deviasi menunjukkan ratarata 19,32 dapat dikatakan bahwa jawaban dari responden bervariasi. Statistik demografi responden dan hasil survei tingkat literasi keuangan mahasiswa FEB Undiksha dalam Tabel 1 dan Tabel2.

Hasil pengujian hipotesis dengan menggunakan analisis jalur (path analysis) dapat dilihat dalam Tabel 3 sampai dengan Tabel 6 .

\section{Tabel 1. Statistik Deskriptif Berdasarkan Demografi Responden}

\begin{tabular}{|c|c|c|}
\hline Variabel & Jumlah Responden & Persentase \\
\hline \multicolumn{3}{|l|}{ Jenis Kelamin } \\
\hline Laki-laki & 46 & $46 \%$ \\
\hline Perempuan & 54 & $54 \%$ \\
\hline \multicolumn{3}{|l|}{ Indeks Prestasi Kumulatif } \\
\hline$<2,5$ & 0 & 0 \\
\hline $2,5-3,00$ & 24 & $24 \%$ \\
\hline$>3$ & 76 & $76 \%$ \\
\hline \multicolumn{3}{|l|}{ Beasiswa } \\
\hline Memperoleh beasiswa & 16 & $16 \%$ \\
\hline Tidak memperoleh beasiswa & 84 & $84 \%$ \\
\hline \multicolumn{3}{|l|}{ Tempat tinggal } \\
\hline Bersama Orang Tua (keluarga) & 52 & $52 \%$ \\
\hline Kost & 48 & $48 \%$ \\
\hline \multicolumn{3}{|l|}{ Penghasilan orang tua } \\
\hline$<1000.000$ & 35 & $35 \%$ \\
\hline $1.000 .000 \mathrm{~s} / \mathrm{d} 5.000 .000$ & 60 & $60 \%$ \\
\hline$>5.000 .000$ & 5 & $5 \%$ \\
\hline
\end{tabular}

Tabel 2. Tingkat Literasi Keuangan Mahasiswa

\begin{tabular}{llllll}
\hline Fakultas & \multicolumn{5}{c}{ Literasi keuangan $(\%)$} \\
\cline { 2 - 5 } & Minimum & Maximum & Mean & St. Deviasi & $\begin{array}{l}\text { Tingkat } \\
\text { Literasi } \\
\text { Keuangan }\end{array}$ \\
\hline Akuntansi S1 & 13 & 100 & 65 & 23 & Sedang \\
\hline Manajemen S1 & 25 & 75 & 54 & 13 & Rendah \\
\hline $\begin{array}{l}\text { Pendidikan } \\
\text { Ekonomi }\end{array}$ & 13 & 63 & 37 & 13 & Rendah \\
\hline D3 Akuntansi & 13 & 88 & 27 & 27 & Rendah \\
\hline
\end{tabular}


Tabel 3. Correlations

\begin{tabular}{llrrr}
\hline & & Perilaku & Pembelajaran di & \\
& & Keuangan & PT & Literasi Keuangan \\
\hline Pearson Correlation & Perilaku Keuangan & 1.000 & .043 & .334 \\
& Pembelajaran di PT & .043 & 1.000 & .033 \\
& Literasi Keuangan & .334 & .033 & 1.000 \\
\hline Sig. (1-tailed) & Perilaku Keuangan &. & .334 & .000 \\
& Pembelajaran di PT & .334 &. & .372 \\
& Literasi Keuangan & .000 & .372 & 100 \\
\hline $\mathrm{N}$ & Perilaku Keuangan & 100 & 100 & 100 \\
& Pembelajaran di PT & 100 & 100 & 100 \\
\hline
\end{tabular}

Tabel 4. Model Summary

\begin{tabular}{|c|c|c|c|c|c|c|c|c|c|c|}
\hline \multirow[b]{2}{*}{ Model } & \multirow[b]{2}{*}{$\mathrm{R}$} & \multirow[b]{2}{*}{ R Square } & \multirow[b]{2}{*}{$\begin{array}{l}\text { Adjusted R } \\
\text { Square }\end{array}$} & \multirow[b]{2}{*}{$\begin{array}{l}\text { Std. Error of } \\
\text { the Estimate }\end{array}$} & \multicolumn{5}{|c|}{ Change Statistics } & \multirow[b]{2}{*}{$\begin{array}{l}\text { Durbin- } \\
\text { Watson }\end{array}$} \\
\hline & & & & & $\begin{array}{c}\text { R Square } \\
\text { Change }\end{array}$ & F Change & df1 & df2 & $\begin{array}{c}\text { Sig. F } \\
\text { Change }\end{array}$ & \\
\hline 1 & $.335^{\mathrm{a}}$ & .112 & .094 & 5.840 & .112 & 6.137 & 2 & 97 & .003 & 1.775 \\
\hline
\end{tabular}

a. Predictors: (Constant), Literasi Keuangan, Pembelajaran di PT

b. Dependent Variable: Perilaku Keuangan

Tabel 5. ANOVA ${ }^{b}$

\begin{tabular}{llrrrrr}
\hline Model & & Sum of Squares & Df & Mean Square & F & \multicolumn{1}{c}{ Sig. } \\
\hline 1 & Regression & 418.571 & 2 & 209.285 & 6.137 & $.003^{\mathrm{a}}$ \\
& Residual & 3308.019 & 97 & 34.103 & & \\
& Total & 3726.590 & 99 & & & \\
\hline
\end{tabular}

a. Predictors: (Constant), Literasi Keuangan, Pembelajaran di PT

b. Dependent Variable: Perilaku Keuangan

Tabel 6. Coefficients ${ }^{\mathrm{a}}$

\begin{tabular}{|c|c|c|c|c|c|c|}
\hline \multirow[b]{2}{*}{ Model } & & \multicolumn{2}{|c|}{ Unstandardized Coefficients } & \multirow{2}{*}{$\begin{array}{c}\begin{array}{c}\text { Standardized } \\
\text { Coefficients }\end{array} \\
\text { Beta }\end{array}$} & \multirow[b]{2}{*}{$\mathrm{T}$} & \multirow[b]{2}{*}{ Sig. } \\
\hline & & B & Std. Error & & & \\
\hline \multirow[t]{3}{*}{1} & (Constant) & 29.470 & 4.655 & & 6.331 & .000 \\
\hline & $\begin{array}{l}\text { Pembelajar } \\
\text { an di PT }\end{array}$ & .021 & .061 & .032 & .338 & .736 \\
\hline & $\begin{array}{l}\text { Literasi } \\
\text { Keuangan }\end{array}$ & .093 & .027 & .333 & 3.474 & .001 \\
\hline
\end{tabular}

a. Dependent Variable: Perilaku Keuangan

a. Pengujian hipotesis secara keseluruhan

Dari hasil pengolahan data program SPSS versi 16, tampak bahwa tabel Correlations, Model Summary, Anova, dan Coefficients ditunjukkan oleh Standardized Coefficients Beta, sedang- kan Unstandardized Coefficients merupakan koefisien regresi biasa. Pengujian secara keseluruhan ditunjukkan dalam tabel 5 Anova yang diperoleh nilai $\mathrm{F}$ sebesar 6,137 dengan nilai probabilitas $($ sig $)=0,003$. Karena nilia sig $<0,05$, maka keputusannya Ho ditolak dan Ha diterima, yang 
berarti pengujian secara individu dapat dilakukan.

b. Pengujian hipotesis secara individual

1) Pembelajaran di perguruan tinggi $\left(X_{1}\right)$ berkontribusi secara signifikan terhadap perilaku keuangan (Y)

Berdasarkan tabel 5 Coefficients diper-oleh variabel pembelajaran di perguruan tinggi nilai sig. sebesar 0,736. Karena nilia sig $>0,05(0,736$ $>0,05)$, maka keputusannya Ho diterima dan Ha ditolak, yang berarti pembelajaran di perguruan tinggi tidak berkontribusi secara signifikan terhadap perilaku keuangan.

2) Literasi keuangan $\left(X_{2}\right)$ berkontribusi secara signifikan terhadap perilaku keuangan (Y)

Berdasarkan tabel 5 Coefficients diperoleh variabel pembelajaran di perguruan tinggi nilai sig. sebesar 0,001. Karena nilai sig $<0,05(0,001$ $<0,05)$, maka keputusannya Ho ditolak dan $\mathrm{Ha}$ diterima, yang berarti literasi keuangan berkontribusi secara signifikan terhadap perilaku keuangan.

Kerangka hubungan kausal empiris antara jalur $\left(\mathrm{X}_{1}\right.$ terhadap $\mathrm{Y}, \mathrm{X}_{2}$ terhadap $\mathrm{Y}$ dan $\mathrm{X}_{1} \mathrm{X}_{2}$ terhadap $\mathrm{Y}$ ) dapat dibuat melalui persamaan struktural sebagai berikut.

$Y=\rho_{y x 1} x 1+\rho_{y x 2} x 2+\rho_{y} \varepsilon$
$Y=0,032 X_{1}+0,333 X_{2}+0,888 \mathrm{e}$

$\mathrm{R}_{\mathrm{yx} 1 . \times 2}^{2}=0,112$

$\mathrm{Py}=1-\mathrm{R}_{\text {yx1.x2 }}^{2}=1-, 112=0,888$

3) Pembelajaran di perguruan tinggi $\left(X_{1}\right)$ dan literasi keuangan $\left(X_{2}\right)$ berkontribusi secara simultan dan signifikan terhadap perilaku keuangan (Y)

Pengaruh bersama atau koefisien $\mathrm{X}_{1}$ dan $\mathrm{X}_{2}$ terhadap $\mathrm{Y}$ atau koefisien determinan dapat dilihat dalam tabel 4 Model Summary. Dalam tabel tersebut dapat dilihat nilai $R$. Square sebesar 0,112 . Angka tersebut mempunyai makna besarnya kontribusi variabel independen exogenus pembelajaran di perguruan tinggi $\left(\mathrm{X}_{1}\right)$ dan literasi keuangan $\left(\mathrm{X}_{2}\right)$ terhadap perilaku keuangan (Y) secara bersama-sama adalah sebesar $11,2 \%$ $(0,112 \times 100 \%)$. Sisanya $\left(1-R^{2}\right)=0,888$ atau $88,8 \%$ mempunyai makna besarnya faktor lain di luar variabel $\mathrm{X}_{1}$ dan $\mathrm{X}_{2}$ yang mempengaruhi $\mathrm{Y}$.

Nilai Sig. $F_{\text {Change }} 0,003<0,05$, maka keputusannya Ho ditolak dan Ha diterima, yang berarti pembelajaran di perguruan tinggi dan literasi keuangan berkontribusi secara simultan dan signifikan terhadap perilaku keuangan. Hasil penelitian di atas, dapat diringkas dalam Tabel 7.

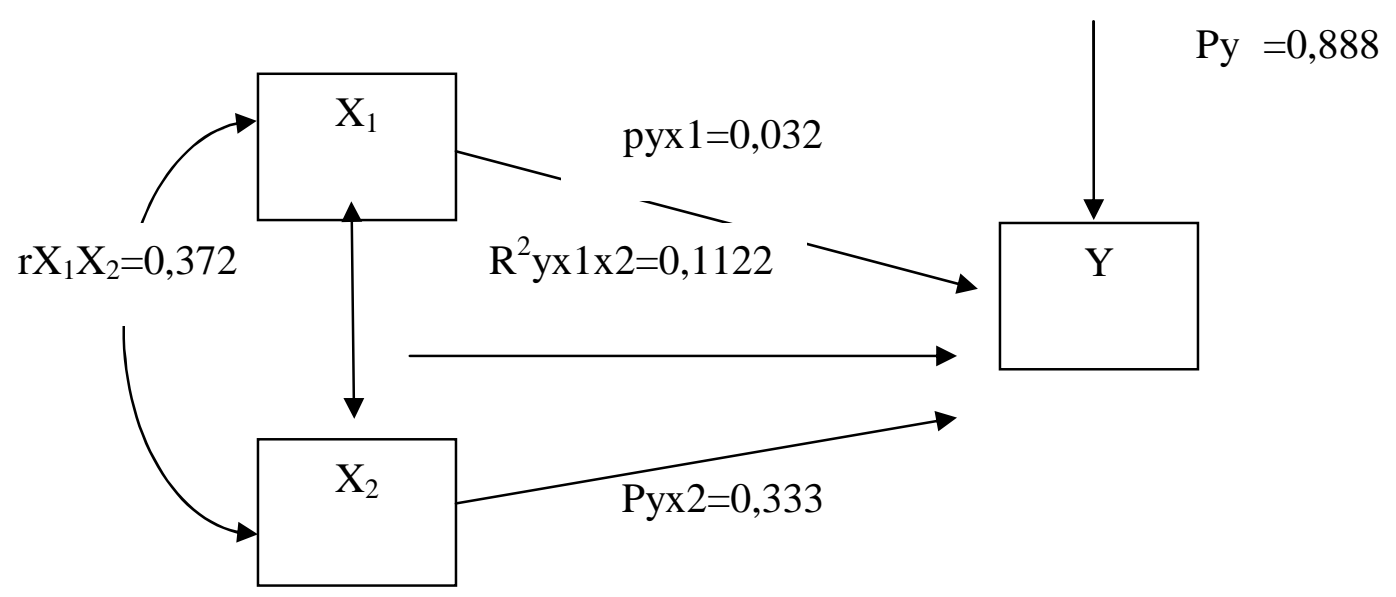

Gambar 2. Struktur Hubungan Kausal X1 dan X2 terhadap Y

Tabel 7. Koefisien Jalur, Kontribusi Langsung, Tidak Langsung, Kontribusi Total dan Kontribusi Pembelajaran di PT $\left(X_{1}\right)$; Literasi Keuangan $\left(X_{2}\right)$; secara Simultan dan Signifikan terhadap Perilaku Keuangan (Y)

\begin{tabular}{l|ccccc}
\hline Variabel & $\begin{array}{c}\text { Koefisien } \\
\text { Jalur }\end{array}$ & Langsung & Tdk.langsung & Total & Kontribusi Bersama \\
\cline { 5 - 6 } & 0,032 & 0,032 & - & $0,10 \%$ & - \\
\hline $\mathrm{X}_{1}$ & 0,333 & 0,333 & - & $11,08 \%$ & - \\
\hline $\mathrm{X}_{2}$ & 0,888 & 0,888 & - & $88,8 \%$ & - \\
\hline $\mathrm{X}_{1}$ dan $\mathrm{X}_{2}$ & - & - & - & - & 0,112 atau $11,2 \%$ \\
\hline
\end{tabular}




\section{Pembahasan}

Pembelajaran di perguruan tinggi $\left(\mathrm{X}_{1}\right)$ berkontribusi secara signifikan terhadap perilaku keuangan (Y)

Temuan penelitian ini menunjukkan bahwa pembelajaran di perguruan tinggi tidak berkontribusi secara signifikan terhadap perilaku keuangan mahasiswa. Hal ini berarti bahwa hipotesis 1 ditolak, yang dilihat dari nilai sig. $>0,05$ $(0,736>0,05)$.

Pembelajaran di perguruan tinggi, terkait dengan pembelajaran keuangan yang diberikan di fakultas ekonomi dan bisnis, meliputi mata kuliah manajemen keuangan, penganggaran, akuntansi pengantar, dan pasar modal. Manajemen keuangan, merupakan mata kuliah yang membahas tentang pengelolaan keuangan (manajemen) pada perusahaan, namun jika dikaitkan dengan perilaku keuangan, maka manajemen keuangan diarahkan pada pengelolaan keuangan pribadi (personal finance). Pengantar Akuntansi I membahas tentang proses akuntansi pada perusahaan jasa dan dagang. Dalam hubungannya dengan perilaku keuangan, mata kuliah ini memberikan pemahaman akan pencatatan transaksi keuangan. Mata kuliah penganggaran, merupakan mata kuliah yang membahas tentang cara menyusun anggaran (forecast) dalam hubungannya dengan perilaku keuangan, maka penganggaran itu memberkan pengetahuan bagaimana membuat perencanaan anggaran keuangan pribadi untuk masa kini dan masa yang akan datang. Investasi dan pasar modal, merupakan mata kuliah yang membahas tentang teknik-teknik berinvestasi pada pasar modal. Dalam hubungannya dengan perilaku keuangan, maka mata kuliah investasi dan pasar modal memberikan pemahaman siswa akan jenis-jenis investasi berikut keuntungan dan kelemahannya sehingga siswa memahami konsep investasi yang benar. Disamping materi keuangan, pembelajaran juga terkait dengan proses dan asesmen. Melalui berbagai metode pengajaran, media, dan sumber belajar yang sesuai dengan kompetensi, diharapkan mampu memberikan bekal kepada mahasiswa untuk memiliki kecakapan di bidang keuangan, sehingga mahasiswa menjadi siap dan mampu menghadapi kehidupan saat ini maupun masa depan yang semakin kompleks (Lutfi dan Iramani, 2008).

Penelitian Lutfi dan Iramani (2008) serta Susanti (2013), menyatakan bahwa pembelajaran di perguruan tinggi berpengaruh pada literasi keuangan. Jhonson dan Margaret (dalam Susanti,
2013) menyatakan bahwa pendidikan keuangan memiliki peran yang sangat penting bagi siswa untuk memiliki kemampuan memahami, menilai dan bertindak dalam kepentingan keuangan mereka. Temuan penelitian ini tidak sejalan dengan penelitian Lutfi dan Iramani (2008) serta Susanti (2013). Mengkaji sistem pembelajaran keuangan di FEB Undiksha, ditemukan bahwa dari keempat mata kuliah keuangan yang relevan dengan literasi keuangan, tidak sepenuhnya terdapat dalam kurikulum masing-masing jurusan. Hal ini berdampak pada kedalaman kajian materi keuangan yang diberikan bervariasi. Disamping itu, materi dalam mata kuliah-mata kuliah tersebut masih disampaikan secara utuh atau lebih menekankan pada keperluan entitas (perusahaan), sehingga tidak menyentuh aspek pengetahuan keuangan pribadi. Hal ini sebenarnya dapat diantisapasi melalui pemberian contoh kasus penerapan riil dalam kehidupan keuangan sehari-hari. Sebagai contoh, materi dalam Akuntansi Pengantar 1 yang mempelajari mengenai proses akuntansi. Mahasiswa hanya diberikan contoh menganalisis transaksi keuangan dalam perusahaan jasa. Mereka diminta mencatat transaksi ke dalam jurnal, misalnya untuk akun kas maka, "debet" berarti pemasu-kan dan "kredit" untuk pengeluaran. Konsep ini jika dikaitkan dengan perilaku keuangan, maka dosen dapat memberikan contoh untuk pengelolaan keuangan pribadi bagaimana mengatur pengeluaran uang dengan bijak.

Sementara itu, dari data demografi menunjukkan bahwa IPK mahasiswa tergolong baik (rata-rata $>3,0$ ). Namun hal ini tidak berbanding lurus dengan tingkat literasi keuangan mahasiswa yang tergolong masih rendah. Tingkat literasi keuangan merupakan indikator dalam berperilaku keuangan (Lusardi dan Tufano, 2008). Hal ini memperkuat temuan penelitian ini bahwa pembelajaran di perguruan tinggi tidak berkontribusi secara signifikan terhadap perilaku keuangan. Hal ini didukung hasil penelitian Susanti (2013) yang menyatakan bahwa faktor-faktor pembelajaran ekonomi di sekolah tidak berpengaruh terhadap literasi keuangan siswa SMA Negeri di Surabaya.

Berdasarkan hal diatas, sudah seharusnya perguruan tinggi berperan penting dalam memajukan tingkat literasi keuangan peserta didiknya. Literasi keuangan merupakan pondasi yang dapat membentuk perilaku keuangan yang baik. Perilaku keuangan yang baik dapat ditunjukkan melalui keputusan-keputusan keuangan yang diambil secara tepat serta menghargai nilai dari uang. Se- 
hingga lulusan perguruan tinggi nantinya tidak hanya memiliki keahlian bidang ilmu sesuai dengan jurusannya, namun juga memiliki literasi keuangan yang baik untuk menata masa depan dengan lebih baik.

\section{Literasi keuangan $\left(\mathrm{X}_{2}\right)$ berkontribusi secara} signifikan terhadap perilaku keuangan (Y)

Hasil penelitian ini menunjukkan literasi keuangan berkontribusi secara positif dan signifikan terhadap perilaku keuangan. Hal ini dibuktikan dari nilai sig < 0,05 $(0,001<0,05)$, sehingga Ho ditolak dan Ha diterima, yang berarti literasi keuangan berkontribusi secara signifikan terhadap perilaku keuangan. Arah positif yang ditunjukkan diartikan bahwa semakin tinggi tingkat literasi keuangan seseorang, maka semakin baik perilaku keuangannya.

Literasi keuangan didefinisikan sebagai kecerdasan atau kemampuan seseorang dalam mengelola keuangannya. Literasi keuangan merupakan suatu keharusan bagi setiap individu agar terhindar dari masalah keuangan. Hal ini disebabkan karena sering kali individu dihadapkan pada trade off yaitu situasi dimana seseorang harus mengorbankan salah satu kepentingan demi kepentingan lainnya. Masalah trade off terjadi karena seseorang dibatasi oleh kemampuan finansialnya untuk memperoleh semua barang yang diinginkan. Untuk itu literasi keuangan mempengaruhi hampir semua aspek yang berhubungan dengan perencanaan dan pengeluaran uang meliputi pendapatan, penggunaan kartu kredit, tabungan, investasi, manajemen keuangan, dan pembuatan keputusan keuangan (Laily, 2013)

Penelitian ini mendukung penelitian Lusardi dan Tufano (2008), Laily (2013) yang menyatakan terdapat pengaruh signifikan antara literasi keuangan dan perilaku keuangan mahasiswa. Mahasiswa yang memiliki pengetahuan yang cukup akan konsep-konsep keuangan akan memiliki sikap yang lebih bijaksana terhadap pengelolaan keuangannya. Byrne (dalam Sina dan Nggili, 2013) menemukan bahwa pengetahuan keuangan yang rendah akan menyebabkan pembuatan rencana keuangan yang salah, dan menyebabkan bias dalam pencapaian kesejahteraan di saat usia tidak produktif lagi. Hal serupa diungkapkan dalam Lusardi, dkk. (2010) yang menyatakan bahwa kurangnya pengetahuan keuangan seseorang dapat menyebabkan kesalahan dalam pengambilan keputusan mengenai utang. Hal ini mengindikasikan diperlukannya literasi keuangan yang memadai, sebagai dasar pengambilan keputusan keuangan yang baik untuk masa kini dan masa mendatang.

Pembelajaran di perguruan tinggi $\left(X_{1}\right)$ dan Literasi keuangan $\left(\mathbf{X}_{2}\right)$ berkontribusi secara simultan dan signifikan terhadap perilaku keuangan (Y)

Temuan dalam penelitian ini menunjukkan bahwa pembelajaran di perguruan tinggi dan Literasi keuangan berkontribusi secara simultan dan signifikan terhadap perilaku keuangan. Hal ini dapat dilihat dari nilai Sig. F Change $0,003<$ 0,05, maka keputusannya Ho ditolak dan $\mathrm{Ha}$ diterima, yang berarti pembelajaran di perguruan tinggi dan literasi keuangan berkontribusi secara simultan dan signifikan terhadap perilaku keuangan. Secara simultan literasi keuangan dan perilaku keuangan berkontribusi secara signifikan terhadap perilaku keuangan sebesar $11,2 \%$. Sisanya yaitu $88,8 \%$ merupakan pengaruh yang datang dari faktor lain di luar penelitin ini, seperti misalnya status sosial ekonomi, gender, lingkungan keluarga, pendidikan keuangan keluarga, dan lainnya. Dilihat dari persentase simultan yang hanya $11,2 \%$, dapat diartikan bahwa variabel pembejaran di perguruan tinggi dan literasi keuangan kurang memberikan pengaruh yang besar terhadap perilaku keuangan seseorang.

Margaretha dan Pambudhi (2015), menemukan bahwa jenis kelamin, usia, IPK dan pendapatan orang tua memiliki pengaruh terhadap literasi keuangan mahasiswa. Hal ini mengindikasikan bahwa literasi keuangan yang dapat mempengaruhi perilaku keuangan juga dipengaruhi oleh faktor individu atau sosial ekonomi seseorang. Misalkan jenis kelamin, Danes \& Haberman (2007), mengungkapkan bahwa perempuan lebih memiliki pengetahuan dalam membedakan antara kebutuhan dan keinginan, sedangkan pria lebih memiliki pengetahuan keuangan yang lain seperti, manajemen kredit, investasi, dan asuransi. Hal ini membuktikan bahwa pria memiliki literasi keuangan (pengetahuan keuangan) yang lebih baik yang berdampak pada perilaku keuangan yang lebih baik pula. Disamping itu faktor eksternal lainnya yang berpengaruh cukup signifikan adalah faktor lingkungan keluarga. Susanti (2014) yang mengungkapkan terdapat pengaruh yang signifikan antara pendidikan keuangan keluarga terhadap literasi keuangan mahasiswa $\mathrm{Fa}$ kutas Ekonomi Unesa. Peran orang tua dalam mengajarkan dan memberikan contoh dalam berperilaku keuangan, dapat membentuk karakteristik dan pola tingkah laku anak. 
Meskipun faktor internal dan eksternal lebih mendominasi perilaku keuangan mahasiswa, peran pembelajaran keuangan dan tingkat literasi keuangan juga turut mempengaruhi. Pembelajaran keuangan selama ini yang hanya lebih menekankan pada keuangan entitas (perusahaan) tidak memberikan makna dalam kehidupan sehari-hari. Sehingga dalam hal ini diperlukan suatu upaya untuk meningkatkan kualitas pembelajaran keuangan yang dapat memberikan pemahaman tentang keuangan pribadi (personal finance). Demikian halnya dengan literasi keuangan. Literasi keuangaan merupakan pengetahuan dan keterampilan dalam pengelolaan keuangan yang menjadi pedoman dalam berperilaku keuangan. Tidak dapat dipungkiri, bahwa saat ini kita hidup dalam era konsumerisme. Hampir semua jenis barang dan jasa menjadi sangat mudah didapatkan. Dengan makin maraknya tawaran pembelian barang secara mencicil, semua barang yang sebelumnya sulit untuk didapatkan, menjadi lebih mudah untuk didapatkan. Di satu sisi, kondisi ini tentunya memberikan manfaat dan kemudahan bagi masyarakat. Namun di sisi lain, jika kita tidak bijaksana menyikapinya, kita dapat terjebak menjadi orang yang lebih mengutamakan 'keinginan' dan melupakan 'kebutuhan' dasar yang seharusnya diprioritaskan.

\section{SIMPULAN}

Berdasarkan hasil penelitian di atas, maka dapat dipaparkan simpulan sebagai berikut. Pertama, pembelajaran di perguruan tinggi $\left(\mathrm{X}_{1}\right)$ yang diukur oleh perilaku keuangan (Y) tidak memiliki kontribusi yang signifikan terhadap perilaku keuangan mahasiswa. Hal ini dapat dilihat dari kontribusi pembelajaran di perguruan tinggi $\left(\mathrm{X}_{1}\right)$ secara langsung yang hanya sebesar $(0,032)^{2}$ $=0,10 \%$. Kedua, literasi keuangan $\left(\mathrm{X}_{2}\right)$ yang diukur oleh perilaku keuangan (Y) memiliki kontri-

\section{DAFTAR RUJUKAN}

Azwar, S. 2009. Sikap Manusai Teori dan Pengukurannya. Yogyakarta: Pustaka Pelajar.

Chen, H. \& Volpe, R. P. 1998. An Analysis of Personal Literacy Among College Students. Financial Services Review, 7(2): 107-128.

Danes, S. M. \& Haberman, H. R. 2007. Teen Financial Knowledge, Self-Efficacy, and Be- busi yang positif dan signifikan terhadap perilaku keuangan mahasiswa. Dengan demikian baik tidaknya perilaku keuangan mahasiswa dapat dijelaskan oleh literasi keuangan. Besarnya kontribusi literasi keuangan secara langsung terhadap perilaku keuangan sebesar $(0,333)^{2}=11,08 \%$. Ketiga, secara simultan pembelajaran di perguruan tinggi $\left(\mathrm{X}_{1}\right)$ dan literasi keuangan $\left(\mathrm{X}_{2}\right)$ berkontribusi secara signifikan terhadap perilaku keuangan (Y) sebesar $11,2 \%$. Sisanya sebesar $88,8 \%$ merupakan pengaruh lain yang tidak dibahas dalam penelitian ini, seperti gender, status sosial ekonomi, pengetahuan, dan lainnya.

Berdasarkan hasil penelitian ini dapat disarankan beberapa hal terkait dengan perilaku keuangan mahasiswa. Pertama, pembelajaran keuangan di perguruan tinggi perlu ditingkatkan dari segi kualitas. Banyaknya materi keuangan yang diberikan jika tidak dikaitkan dengan pengelolaan keuangan pribadi (personal finance), tidak memberikan dampak yang positif bagi mahasiswa untuk berperilaku keuangan yang baik. Untuk itu pemberikan kasus riil yang menyentuh aspek keuangan pribadi, sangat perlu disampaikan. Kedua, peningkatan indeks literasi keuangan mahasiswa. Hal ini dapat ditempuh melalui pembelajaran keuangan yang memadai, maupun sosialisai pengelolaan keuangan melalui seminar-seminar. Ketiga, hasil penelitian ini memberikan kontribusi untuk mengadakan penelitian selanjutnya untuk menganalisis faktor-faktor yang lebih berperan dalam membentuk perilaku keuangan mahasiswa, seperti status sosial ekonomi (SSE), lingkungan sosial, lingkungan keluarga, dan lainnya. Disamping itu pendekatan penelitian kualitatif, dapat dijadikan alternatif penelitian lanjut untuk melengkapi data kuantitatif yang dihasilkan dalam penelitian ini.

havior: A Gendered View. Financial Counceling and Planning. (Online), 18(2): 48-60, (htpp://www.afcpe.org/assets/pdf/72866-volume-18-issue-2.pdf, diakses 2 Agustus 2015).

Danes, S. M. \& Hira, T. K. 1987. Money Manajement Knowledge of Colledge Students. The Journal of Student Financial Aid, (Online), 17 (1): 4-16 (htpp://tkhira.user. 
iastate.edu/file.MMKnowColledgeStu.pdf, diakses 2 Agustus 2015).

Gutter, M. 2008. Financial Manajemen Practices of Collage Student from States With Varying Financial Education Mandates. (Online), (htpp://www.cgsnet.org/ckfinder/ userfiles/files/Gutter_FinMgtPracticesofCo lledgeStudents_Final.pdf, diakses 3 Agustus 2015).

http://www.ojk.go.id/peran-bi, diakses tanggal 7 Februari 2014.

http://bisnis.liputan6.com/read/2071828/soalliterasi-keuangan-ri-kalah-dari-malaysiadan-singapura diakses 7 Februari 2014.

http://www.usfinancialcapability.org/quiz.php.

Jhonson, E \& Margaret, S. S. 2007. From Financial Literacy to Financial Capability Among The Young. Journal of Sociologi and Social Welfare, (Online), 34:119-146. (htpp://www.usc.edu/dept/cheap/HRYAN G/publications/110.pdf, diakses 3 Agustus 2015).

Layli, N. 2013. Pengaruh Literasi Keuangan terhadap Perilaku Mahasiswa dalam Mengelola Keuangan. Artikel. JPA UM Malang. Vol 1. No.4. Hal. 277-285.

Lusardi.A \& Tuffano. P. 2008. Debt Literacy, Financial Experience, and Overindebtedness. Prelimanary and Incomplete Discussion Draft, (Online), (htpp://www.ftc.gov/ be/workshop/mortage/articles/lusarditufan o2008.pdf, diakses 2 Agustus 2015).

Lutfi \& Iramani. 2008. Financial Literacy Among University Student and Its Implications to the Teaching Method. Makalah disajikan dalam Annual SEAAIR Conference STIE Perbanas, Surabaya, 4 Nopember.

Margaretha,F., \& Pambudhi, A. R. 2015. Tingkat Literasi Keuangan pada Mahasiswa S-1 Fakultas Ekonomi. JMK, 17(1): 76-85.

Nidar, S. R., \& Bestari, S. 2012. Personal Literacy Among University Students (Case Studi at Padjajaran University Strudents, Bandung, Indonesia. World Journal of Social Sciences, 2(4): 162-171.
Riduwan \& Kuncoro, E. A. 2007. Cara Menggunakan dan Memakai Analisis Jalur (Path Analysis). Bandung: Alfabeta.

Robb, C. A. \& Woodyard, A. S. 2011. Financial Knowledge and Best Practice Behavior. Journal of Financial Conseling and Planning, (Online), 22(1): 60-70, (htpp://www. afcpe.org/assets/pdf/vol22_issue 1 robbwoodyard.pdf), diakses 2 Agustus 2015.

Sarwono, J. 2011. Path Analysis (Teori, Aplikasi, Prosedur Analisis untuk Riset Skripsi, Tesis, dan Desertasi (Menggunakan SPSS). Jakarta: PT Elex Media Komputindo.

Sina, G. P. 2011. Keuangan Berbasis Perilaku (Behaviour Finance), (Online), (htpp:// www.ziddu.com/download/17975405/Keu angan Berbasis Perilaku.pdf.html, diakses 20 Agustus 2015).

Susanti. 2013. Faktor-Faktor yang Mempengaruhi Perilaku Keuangan Siswa SMA di Surabaya. Desertasi tidak diterbitkan. Malang: PPS UM.

Susanti. 2014. Pentingnya Literasi Keuangan bagi Generasi Muda di Surabaya, Makalah, disajikan pada SNE Pembangunan Manusia Melalui Pendidikan Dalam Menghadapi ASEAN Economic Community 2015, Surabaya, 3 Mei.

Trianto. 2009. Mendesain Model Pembelajaran Inovatif-Progresif. Jakarta: Kencana Prenada Media Group.

Widayati, I. 2011. Pengaruh Status Sosial Ekonomi Orang Tua, Pendidikan Pengelolaan Keuangan Keluarga, dan Pembelajaran di Perguruan Tinggi terhadap Literasi Finansial Mahasiswa Fakultas Ekonomi dan Bisnis Universitas Brawijaya. Tesis tidak diterbitkan. Malang:PPS UM.

Wahyono, H. 2001. Pengaruh Perilaku Ekonomi Kepala Keluarga terhadap Intensitas Pendidikan Ekonomi di Lingkungan Keluarga. Desertasi tidak diterbitkan. Malang: PPS UM. 